\title{
Innovations in design and construction of granular pavements and railways
}

\author{
A. Gomes Correia \\ Department of Civil Engineering, University of Minho, Guimarães, Portugal
}

ABSTRACT: This paper describes some of the work related with the International Technical Committee TC3 - Geotechnics of Pavements of ISSMGE. For brevity, some topics are selected to be described in some detail, while others are acknowledged for reference purposes. These topics cover: (1) Data Mining tools in transportation geotechnics showing the capabilities to predict real-value from several attributes and also the possibility to develop a formal updating framework to reduce uncertainty and increase reliability of deformability modulus updating in pavement and rail track structures; (2) Design aspects related with the mechanist approach in the framework of soil mechanics; (3) construction and quality control aspects covering compactor technologies and advanced tools for continuous compaction control and bearing capacity surveys during and after construction.

These contributions aim to promote the use of some powerful available tools in the design and construction processes with impacts in the reduction of maintenance costs.

\section{REFERENCES}

Adam, D. 2007. Roller-integrated continuous compaction control (CCC). Technical contractual provisions \& recomendations. Design and Construction of Pavements and Rail Tracks. (Gomes Correia, Momoya, Tatsuoka, eds). Balkema, Leiden, The Netherlands, 111-138.

Adam,D.,Kopf, F. 2000. Sophisticated compaction technologies and continuous compaction control. Compaction of Soils and Granular Materials (Gomes Correia \& Quibel, eds). Presses de l'Ecole Nationale des Ponts et Chaussées, Paris, 207-220.

Adam, D., Markiewicz, R. 2001. Compaction behaviour and depth effect of the Polygon-Drum. Geotechnics for Roads, Rail Tracks and Earth Structures (Gomes Correia \& Brandl, eds), Balkema, The Netherlands, 27-36. Atkinson, J.H., Sallfors, G. 1991. Experimental determination of stress strain-time characteristics in laboratory and in situ tests. Proc. 10th ECSMFE, Deformation of Soils and Displacements of Structures, Associazione Geotecnica Italiana, Vol. III, 915-956.

Berggren, E. 2005. Dynamic track stiffness measurement. A new tool for condition monitoring of track substructure. Royal Institute of Technology. Thesis.

Brandl, H. 2001a. Compaction of soil and other granular material - interactions. Geotechnics for Roads, RailTracks and Earth Structures (Gomes Correia \& Brandl, Eds), Balkema, The Netherlands, 3-11.

Brandl, H. 2001b. High embankments instead of bridges and bridges foundations in embankments. Geotechnics for Roads, Rail Tracks and Earth Structures (Gomes Correia \& Brandl, Eds), Balkema, The Netherlands, 13-26.

Brandl, H. 2001c. The importance of optimum compaction of soil and other granular materials. Geotechnics for Roads, Rail Tracks and Earth Structures (Gomes Correia \& Brandl, Eds). Balkema, The Netherlands, 47-66.

Brown, S.F. 1996. 36th Rankine lecture: Soil Mechanics in Pavement Engineering, Géotechnique, 46: 3, 383-426. 
Brown, S.F. 2004. Design considerations for pavement and rail track foundations. Geotechnics in Pavement and Railway Design and Construction (Gomes Correia \& Loizos, Eds), MillPress, Rotterdam, Netherlands.

Brown, S.F. 2007. The effect of shear reversal on the accumulation of plastic strain in granular materials under cyclic loading. Design and Construction ofPavements and Rail Tracks. (Gomes Correia, Momoya, Tatsuoka, eds.). Balkema, Leiden, The Netherlands, 89-108.

Clark, M.R., Gordon, M., Forde, M.C. 2004. Issues over high-speed non-invasive monitoring of railway trackbed. NDT\&E International, 37: 131-139.

Cortez, P. 2008. RMiner: Data Mining with Neural Networks and SupportVector Machines using $\mathrm{R}$, In R. Rajesh (Ed.), Introduction to Advanced Scientific Softwares and Toolboxes, International Association for Engineering (IAEng), In press.

Edil, T.B., Sawangsuriya, A. 2005. Earthwork quality control using soil stiffness. Proc. XVI ICSMGE, Millpress, Rotterdam, The Netherlands.

Einstein, H. 1988. Landslide risk assessment procedure. In Proc. 5th Int. Symp. on Landslides. Keynote paper. Lausanne, Switzerland.

Einstein, H. 2004. The Decision Aids for Tunnelling (DAT) - an update. Transportation Research Record, 1892: 199-207.

Einstein, H., C. Indermitte, J. Sinfield, F. Descoeudres, and J. Dudt. 1999. The Decision Aids for Tunnelling. Transportation Research Record, 1656. EN 13286-7 - 2004. Unbound and hydraulically bound mixtures - Part 7: Cyclic load triaxial test for unbound mixtures.

Faber, M. 2005. Risk and safety in civil, surveying and environmental engineering. Swiss Federal Institute of Technology. Lecture notes. Zurich, $394 \mathrm{p}$.

Fayyad, U., Piatetsky-Shapiro, G. and Smyth, P. 1996. Advances in Knowledge Discovery and Data Mining. MIT Press.

Fernandes, F., Oliveira, M. Gomes Correia, A., Lourenço, P.B., Caldeira, L. 2008. Assessment of layer thickness and uniformity in railway embankments with GPR. 1st

Conference on Transportation Geotechnics.

Flemming, P. and Rogers, C. 1995. Assessment of pavement foundations during construction. Paper 10625, Proc. Inst. Civil Engineers Transportation, 111, pp. 105-115.

Flood, I., and Kartam, N. 1994. Neural networks in civil engineering I: Principles and understanding. J. Computing in Civil Engrg, ASCE, 8(2), 131-148.

Goh, A. T. C. 1995. Empirical design in geotechnics using neural networks. Geotechnique, 45(4), 709-714.

Gomes Correia A., Ferreira S. M. R., Roque A. J., Castro F., CavalheiroA. 2008. Environmental and engineering properties for processed Portuguese steel slags, Green5 Conference, Vilnius, Lithuania (submitted).

Gomes Correia, \& Brandl, H. (Editors). Geotechnics for Roads, Rail Tracks and Earth Structures. Balkema, Lisse, The Netherlands, 2001.

Gomes Correia, A \& Quibel, Alain (Editors). Compaction of Soils and Granular Materials. Presses de l' Ecole Nationale des Ponts et Chaussées, Paris, 2000.

Gomes Correia, A., Momoya, Y., F. Tatsuoka (Editors). Design and Construction of Pavements and Rail Tracks. Geotechnical aspects and processed materials. Balkema, Leiden, The Netherlands, 2007.

Gomes Correia, A. 2001. Soil Mechanics in routine and advanced pavement and rail track rational design. Geotechnics for Roads, Rail tracks and Earth Structures (Gomes Correia \& Brandl, eds.). Balkema, pp. 165-187.

Gomes Correia, A. 2004. Evaluation of mechanical properties of unbound granular materials for pavements and rail

tracks, keynote lecture. Pavement and railway Design and Construction (Gomes Correia \& Loizos, eds.), Millpress, 35-60. 
Gomes Correia, A., Lacasse, S. 2006. Marine and transportation geotechnical engineering Technical Session 2e. Proc. XVI ICSMGE, Millpress, Rotterdam, The Netherlands, vol. 5, 30453069.

Gomes Correia, A., Lacasse, S., Ohtsuka, S. 2006. Marine and transportation geotechnical engineering - session 2e, General report. Proc. XVI ICSMGE, Millpress, Rotterdam, The Netherlands, vol. 5, 3185-3188.

Gomes Correia, A., Momoya, Y., Tatsuoka, F. 2006. TC 3 Workshop - Geotechnical aspects related to foundation layers of pavements and rail track. Proc. XVI ICSMGE, Millpress, Rotterdam, The Netherlands, vol. 5, 3259-

3262.

Gomes Correia, A., Viana da Fonseca, A. and Gambin, M. 2004. Routine and advanced analysis of mechanical in situ tests. Results on saprolitic soils from granites more or less mixed in Portugal. Keynote lecture, ISC'2, Porto. (Viana da Fonseca and Mayne, eds.), Millpress, Rotterdam.

Gomes Correia, A., Loizos, A. (Editors). Geotechnics in Pavement and Railway Design and Construction, Mill- Press, Rotterdam, Netherlands, Athens, 2004.

Karam, J. 2005. Decision Aids for Tunnel Exploration. Master's thesis, Massachusetts Institute of Technology, Massachusetts, USA.

Kröber, W., Floss, E.H.R., Wallrath, W. 2001. Dynamic soil stiffness as quality criterion for soil compaction. Geotechnics for Roads, Rail tracks and Earth Structures (Gomes Correia and Brandl, eds.). Balkema, pp. 189-199.

Lee, J.L., Stokoe, II, K.H., Bay, J.A. 2005. The rolling dynamic deflectometer: A tool for continuous deflection profiling of pavements. Proc. XVI ICSMGE, Millpress, Rotterdam, The Netherlands, vol. 3, 1745-1748.

Marques, R., Gomes Correia, A., Cortez, P. 2008. Data Mining in the "Technical Guide for Road Earthworks" - GTR (in Portuguese). 11th Portuguese Geotechnical Congress, Coimbra, Portugal, vol. III, 285-291.

Min, S., H. Einstein, Lee, J. 2005. Application of the Decision Aids for Tunnelling (DAT) to update excavation cost/time information. KSCE J. of Civil Engineering, 9(4).

Miranda, T. 2007. Geomechanical parameters evaluation in underground structures. Artificial intelligence, Bayesian probabilities and inverse methods. PhD thesis. University of Minho, Guimarães, Portugal, 291p.

Mohamed A. Shahin, Mark B. Jaksa and Holger R. Maier 2001. Artificial Neural Network Applications in Geotechnical Engineering. Australian Geomechanics - March 2001.

Momoya,Y., Sekine, E. 2005. Deformation characteristics of railway asphalt roadbed under a moving wheel load. XVI ICSMGE, Millpress, Rotterdam, The Netherlands.

Narayanan, R.M., Jakub, J.W., Li,D., Elias S.E.G. 2004. Railroad track modulus estimation using ground penetrating radar measurements. NDT\&E International, 37: 141-151.

Nazarian, S. and Desai, M.R. 1993 Automated Surface Wave Method: Field Testing, Journal of the Geotechnical Engineering Division, ASCE, Vol. 119, No. GT7, ASCE. NF P 94-117-1 2000. "Sols: reconnaissance et essais. Portance des plates-formes. Partie 1: Module sous chargement statique à la plaque (EV2)». Association Française de Normalisation (AFNOR).

Pinard, M.I. 2001. Developments in compaction technology. Geotechnics for Roads, Rail Tracks and Earth Structures (Gomes Correia \& Brandl, eds.). Balkema, Lisse, The Netherlands, 37-46.

Quibel, A. 1999. New in situ devices to evaluate bearing capacity and compaction of unbound granular materials.

Unbound Granular Materials. Laboratory Testing, In-situ Testing and Modelling (Gomes Correia, ed.), A.A. Balkema, Rotterdam, The Netherlands, 141-151. Rasmussen, S., Krarup, J.A. and Hildebrand, G. 2002. Noncontact deflection measurement at high speed. Bearing Capacity of Roads, Railways and Airfields (Gomes Correia \& Branco, eds.), Balkema, 1, pp. 53-60.

Saarenketo, T. 1992. Ground penetrating radar. Applications in road design and construction in Finish Lapland. 
Geological Survey of Finland, Special paper 15, 161-167.

Saarenketo, T. 1999. Road analysis, an advanced integrated survey method for road condition evaluation. Unbound Granular Materials. Laboratory Testing, In-situ Testing and Modelling. Gomes Correia (ed.), A.A. Balkema, Rotterdam, The Netherlands, 125-133.

SETRA/LCPC 2000. Construction of embankments and capping layers, Fascicules 1 and 2, Technical guide SETRA/LCPC.

Stokoe, II K.H., Allen, J.J., Bueno, J.L., Kalinski, M.E. and Myers, M.L. 1999. In-situ stiffness and density measurements of thik-lift unbound aggregate bases. Unbound Granular Materials, Laboratory Testing, In-situ Testing and Modelling (Gomes Correia ed.), Balkema, pp. 85-96.

Thurner H.F. and Sandstrom, A.J. 2000. Continuous compaction control, CCC. Compaction of Soils and Granular Materials (Gomes Correia \& Quibel, Editors). Presses de l'Ecole Nationale des Ponts et Chaussées, Paris, 237-246.

TR 1999. Use of Artificial Neural Networks in Geomechanical and Pavement Systems.Transportation Research, Circular N. E-C012, TRB / National Research Council.

Wermeister S., Dawson A.R., Frohmut W. 2001. Pavement deformation behavior of granular materials and the shakedown concept. Transportation Research Board. Washington D.C.York, NY.

Yu, Hai-Sui, Li, H., Juspi, S. 2005. Shakedown approach to pavement analysis and design. Personal presentation at the TC3 workshop, XVI ICSMGE, Osaka. 